\title{
Paternity seven years after a negative post- vasectomy semen analysis: a case report
}

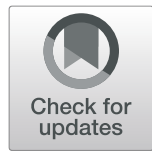

Athena Michaelides ${ }^{1 *}$ and Mehrban Ghani

\begin{abstract}
Background: Vasectomy is one of the permanent methods of contraception; however, the risk of conception still exists. Early failure, defined as a postoperative semen analysis showing persistent motile sperm, occurs in 1 in every 250 patients. Late failure, defined as the rejoining of the severed ends of the vas deferens, occurs in 1 in every 2000 patients.

Case presentation: A healthy 37-year-old British male presented to our clinic because his wife had conceived seven years after he had undergone a vasectomy. The result of his semen analysis after the vasectomy was negative, and the histopathological report confirmed that the sample contained tissue from both the left and right vas deferens. His wife conceived seven years after the procedure, and semen analysis at that time confirmed a total of 0.5 million sperm per milliliter of semen in a total semen sample of $6.3 \mathrm{ml}$. The total number of motile sperm recorded was 2.5 million.

Conclusion: This case shows that late recanalization can occur up to seven years after a vasectomy. Patients should be informed prior to the procedure that late recanalization, although rare, may still occur. Post-vasectomy paternity necessitates further counseling to ensure that the patient and the patient's partner fully understand the implications and options available to them.
\end{abstract}

Keywords: Vasectomy, Recanalization, Paternity, Semen analysis, Conception

\section{Background}

Vasectomy is recognized as one of the permanent methods of contraception; however, the risk of conception after vasectomy still exists [1-3]. Vasectomy failure can be due to technical error during the procedure, early recanalization, late recanalization, or patients' failing to use alternative contraceptive methods immediately after the procedure when sperm could still be present in the ejaculate [4].

There is a general consensus that men are considered sterile if $<100,000$ non-motile spermatozoa per milliliter are present in the ejaculate sample taken three months after the vasectomy $[4,5]$. Early failure, defined as a postoperative semen analysis showing persistent motile

\footnotetext{
* Correspondence: athena1.michaelides@gmail.com

${ }^{1}$ University of Nicosia Medical School, Nicosia, Cyprus

Full list of author information is available at the end of the article
}

sperm, occurs in 1 in every 250 patients. Late failure, defined as the rejoining of the severed ends of the vas deferens, occurs in 1 in every 2000 patients [6]. This report aims to describe the case of a young man who became a father after a negative post-vasectomy semen analysis.

\section{Case presentation}

A healthy 37-year-old British male came to our clinic because his wife had conceived seven years after he had undergone a vasectomy. The decision to have a vasectomy was motivated by him already having two children. The result of his semen analysis post-vasectomy was negative: no sperm were detected in a $5 \mathrm{ml}$ sample of his semen. The histopathological report confirmed that the vasectomy sample contained a strip of tissue $1.5 \mathrm{~cm}$ in length from both the left and right vas deferens. This confirmed that the procedure was carried out 
successfully, and paternity seven years later could not be attributed to technical failure.

Seven years after the procedure, the patient's wife conceived. Semen analysis at this time confirmed that sperm were present within the sample. A total of 0.5 million sperm per milliliter of semen (World Health Organization [WHO] normal reference range, > 15 million $/ \mathrm{ml}$ ) was recorded in a total semen volume of $6.3 \mathrm{ml}$. The total number of progressive motile sperm recorded was 2.5 million (WHO normal reference range, > 7.2 million). This case shows that late recanalization can occur up to seven years after a vasectomy and despite oligospermia, conception is still possible.

\section{Discussion and conclusions}

Vasectomy is one of the safest methods of male contraception. Voluntary vasectomy is available to men of any age and family size as part of advanced family planning [7]. A preoperative discussion between the physician and the patient includes the consideration of the patient's age, his current partnership status, and his irrevocable decision to undergo a procedure with a permanent outcome of sterility. The risks and complications are also discussed [7].

The procedure is usually carried out in an outpatient setting with the patient under local anesthesia, but general anesthesia may be used in some instances. Different vasectomy techiques may be employed. The standard ligation technique consists of identification and resection of $2-4 \mathrm{~cm}$ of the vas deferens. The fulguration technique employs a diathermic needle to create thermal damage to the mucosa of the vas by inducing an inflammatory reaction that results in occlusion. The "no-scalpel" vasectomy employs a clamp to perforate and separate the skin covering the vas. The vas is then grasped with forceps to produce a result similar to that of the fulguration technique [7].

The more common complications of a vasectomy include mild scrotal swelling and bruising, bleeding and postoperative hematoma formation, blood in the semen of the first few postprocedural ejaculations, chronic testicular pain that may affect day-to-day activities, and epididymo-orchitis or testicular infection and inflammation $[6,8]$. The less common complications are early and late failure, which occur in 1 in 250 patients and 1 in 2000 patients, respectively [6].

Studies have shown that early recanalization usually occurs between 2 and 6 weeks post-vasectomy $[9,10]$. Our present case report describes failure due to late recanalization that occurred seven years post-vasectomy. Recanalization occurs when epithelial microtubules proliferate through the granulomatous tissue between the severed ends of the vas deferens producing a fistula that allows sperm to pass through [10]. Recanalization is more likely to occur if less than $1 \mathrm{~cm}$ of the vas is removed during the surgery or if an abscess forms after the procedure [3]. Because our patient's histopathological report confirmed $1.5 \mathrm{~cm}$ of vas removed from each testis, our patient does not fall into the group at high risk of recanalization.

Vasectomy, although mostly successful, still has a degree of failure. Patients should be counseled prior to the procedure that late recanalization may occur in 1 in every 2000 cases. Post-vasectomy paternity necessitates further counseling to ensure that the patient and the patient's partner fully understand the implications and options available to them.

Abbreviation

WHO: World Health Organization

\section{Acknowledgements}

The authors thank the patient for agreeing to have his case published.

\section{Authors' contributions}

AM and MG take full responsibility for the information presented. The authors agree that they have full confidence in the accuracy and integrity of the work. Both authors contributed at all levels, from data collection to the writing and submission of the manuscript. Both authors read and approved the final manuscript.

\section{Funding}

Barnsley Hospital supported funding for the publication of this manuscript. The funders have no direct involvement in the data collection, writing, or submission of the report.

\section{Availability of data and materials}

The patient's information and medical records used for the case report are available from the corresponding author upon request.

Ethics approval and consent to participate

This study did not include experiments on animals or humans. The patient consented to the use of his personal data for the purpose of this case report.

\section{Consent for publication}

Written informed consent was obtained from the patient for publication of this case report and any accompanying images. A copy of the written consent is available for review by the Editor-in- Chief of this journal.

\section{Competing interests}

The authors declare that they have no competing interests. The authors have no association with commercial entities that could provide support for the work reported in this report, nor with entities that could be viewed as having a general interest in the area of the submitted manuscript. The authors have no association with financial or nonfinancial organizations.

\section{Author details}

${ }^{1}$ University of Nicosia Medical School, Nicosia, Cyprus. ${ }^{2}$ White Rose Medical Practice, Cudworth, UK.

Received: 14 November 2019 Accepted: 19 March 2020 Published online: 22 April 2020

\section{References}

1. Jamieson DJ, Costello C, Trussell J, Hillis S, Marchbanks PA, Peterson HB. The risk of pregnancy after vasectomy. Obstet Gynecol. 2004;103(5):848-50. A published erratum appears in Obstet Gynecol. 2004;104(1):200.

2. Lucon M, Kucon AM, Pasqualoto FF, Srougi M. Paternity after vasectomy with two previous semen analyses without spermatozoa. Sao Paulo Med J. 2007;125(2):122-3. 
3. Philip T, Guillebaud J, Budd D. Late failure of vasectomy after two documented analyses showing azoospermic semen. Br Med J (Clin Res Ed). 1984;289:77-9

4. Lowe G. Optimizing outcomes in vasectomy: how to ensure sterility and prevent complications. Transl Androl Urol. 2016;5(2):176-80.

5. Dohle GR, Diemer T, Kopa Z, Krausz C, Giwercman A, Jungwirth A. European Association of Urology guidelines [in Spanish]Actas Urol Esp. 2012;36(5): 276-81.

6. British Association of Urological Surgeons (BAUS). Vasectomy: information about your procedure from the British Association of Urological Surgeons. London: Author: 2017.

7. Weiske WH. Vasectomy. Andrologia. 2001;33:125-34.

8. Raspa RF. Complications of vasectomy. Am Fam Physician. 1993;48(7):12648

9. Lucon AM, Pasqualotto FF, Schneider-Monteiro ED, Saldanha LB, Danilovic A. Spontaneous recanalization after vasectomy. ScientificWorldJournal. 2006; 6:2366-9.

10. Labrecque M, Hays M, Chen-Mok M, Barone MA, Sokal D. Frequency and patterns of early recanalization after vasectomy. BMC Urol. 2006;6:25.

\section{Publisher's Note}

Springer Nature remains neutral with regard to jurisdictional claims in published maps and institutional affiliations.

Ready to submit your research? Choose BMC and benefit from:

- fast, convenient online submission

- thorough peer review by experienced researchers in your field

- rapid publication on acceptance

- support for research data, including large and complex data types

- gold Open Access which fosters wider collaboration and increased citations

- maximum visibility for your research: over $100 \mathrm{M}$ website views per year

At BMC, research is always in progress.

Learn more biomedcentral.com/submissions 